\title{
Microestructuras interfaciales en el hormigón
}

\author{
Interface Microstructures in Concrete
}

FRANCISCA PUERTAS; ANGEL PALOMO y M." TERESA BLANCO

ICCET/CSIC

ESPAÑA

Fecha de recepción: 25-III-91

RESUMEN

El presente trąbajo constituye un resumen y también una interpretación del estado actual del conocimiento respecto de las diferentes microestructuras que se desarrollan en las zonas interfaciales de los hormigones, es decir: pasta de cemento-áridos, pasta de cemento-armaduras, pasta de cemento-fibras, etc. Las reacciones químicas que tienen lugar en la zona interfacial, el desarrollo y morfología de dicha zona y su resistencia (las interfases se consideran como uno de los puntos débiles del hormigón) son los aspectos que con cierto detalle se tratan en el trabajo.

\begin{abstract}
$S \cup M M A R Y$
This paper constitutes a compilation as well as an interpretation of the present state of knowledge about the different microstructures developed in the interface areas of concrete, that is, the cement paste-aggregates, the cement paste-reinforcement, the cement paste-fiber, etc. The chemical reactions taking place in interface areas, the development and morphology of such areas and their strength 'since interfaces are taken as the weakest points of concrete) are the aspects dealt with in some detail in this work.
\end{abstract}

\section{INTRODUCCION}

El progreso alcanzado en los últimos tiempos en el campo de los materiales ha sido el resultado de reconocer que las propiedades de un material derivan de su microestructura.

El hormigón es el material más ampliamente utilizado en la construcción estimándose su consumo en el mundo, en un orden próximo a los 4.500 millones de toneladas/año. Pese a este elevado consumo, el hormigón al poseer una estructura altamente compleja y heterogénea, ha dificultado, hasta la fecha, el desarrollo de modelos útiles que relacionen estructuras propiedades, y que permitan predecir comportamientos.

La caracterización completa de la microestructura de un sólido lleva consigo la determinación de los tipos, cantidades y distribución de todos los constituyentes presentes (1).

Desde un punto de vista macroscópico, el hormigón se compone de dos fases; es decir, de partículas de árido dispersas en una matriz de pasta de cemento (2). A nivel microscópico, la

\section{INTRODUCTION}

The progress recently achieved in the area of materials is the result of having recognised the fact that the properties of a material are a consequence of its microstructure.

Concrete is the material most widely used in construction, its consumption being estimated at approximaltely 4.5 billion tons/year. In spite of this high consumption, and owing to the highly complex and heterogeneous structure of concrete, the development of useful models relating structure-properties to permit behaviour prediction has been difficult to these days.

The full characterisation of the microstructure of a solid entails determining the type, quantity and distribution of each component present(1).

From a macroscopic standpoint, concrete consists of two phases; that is, aggregate particles dispersed in a cement paste matrix (2). At the microscopic level the system complexity is 
complejidad del sistema aumenta, porque ambas fases no estan distribuidas homogeneamente una respecto a la otra, ni son homogeneas en sí mismas.

Puesto que el hormigón, como ya se ha indicado, se puede modelizar como un material compuesto de partículas de áridos dispersas en una matriz de pasta de cemento endurecida, resulta lógico pensar que las características de tal material son el resultado de sumar las propiedades independientes de cada uno de los componentes y de la naturaleza de la interacción entre ellos o, lo que es lo mismo, de la naturaleza de la interfase. Hoy día está ampliamente reconocido que la estructura de la matriz de cemento en las proximidades de los áridos, o en su caso de las fibras o de las armaduras, es muy distinta a la del resto de la pasta, aunque dicha microestructura de la zona interfacial es variable en función de la naturaleza del cemento, del tipo de áridos, de las condiciones de curado, etc.

A pesar de que muchas de las características de la zona interfacial son conocidas, como por ejemplo su espesor (50-100 $\mu \mathrm{m})$, también es cierto que la importancia relativa de todos aquellos factores que contribuyen a la unión entre la pasta de cemento y los áridos, fibras, armaduras, etc. (llámense fuerzas de Van der Waals, fenómenos de crecimiento epitaxial de cristales, etc.) es todavía desconocida. En general, está bastante extendida la idea de que la zona interfacial constituye el punto débil de los sistemas cementicios por ser la zona de mayor porosidad; sin embargo, hasta el momento nadie ha sido capaz de predecir cuánto se podrían mejorar las prestaciones de un hormigón por mejorar la unión matriz-árido (fibra, etc.). Es más, en algunos casos aumentar la resistencia de esta unión puede ir en detrimento del comportamiento en servicio del material.

En el presente trabajo, que es un resumen de otro más exhaustivo realizado recientemente (3), se pretende mostrar un estado del conocimiento sobre los estudios y avances alcanzados hasta la fecha, en torno a la microestructura del hormigón, haciendo especial énfasis en las características microestructurales de la interfase pasta de cemento (árido, armadura, fibra, etc.); y en la relación de éstas con las propiedades del hormigón.

\section{ORIGEN Y DESARROLLO DE LA MICROESTRUCTURA}

La pasta de cemento es el resultado de una serie de reacciones de hidratación que tiene lugar cuando una cantidad determinada de cemento se mezcla con una cantidad limitada de agua. Las reacciones más importantes que ocurren son: increased since both phases are not homogeneously distributed relative to each other, nor are they homogeneous in themselves.

In view of the concrete being able to be modelled, as previously stated, as a material composed of aggregate particles dispersed in a matrix of cured cement paste, it would be logical to think that the characteristics of such material are the sum of the individual properties of each component and a result of the nature of the interaction amongst them or, likewise, from the nature of the interface. It is broadly understood nowadays that the structure of the cement matrix in the vicinity of the aggregates or, if applicable, near the fibers or reinforcements, is very different from the rest of the paste, although such microstructure of the interface area may vary as a function of the type of cement, the nature of the aggregates, the curing conditions, etc.

Despite the fact that many characteristics of the interface area are already known, as per instance its thickness $(50-100 \mu \mathrm{m})$, it is also true that all of the factors contributing to the cement-aggregatesfibres-reinforcement, etc. bond (whether they are called Van der Waals forces, epitaxial crystal growth phenomena, etc.) are still unknown. In general, the idea is rather prevalent that the interface area constitutes the weak point of cement-based systems as it is the higher porosity area; nonetheless, no one until now has been able to predict how much a concrete performance can be improved through an improvement of the matrix-aggregate (fiber, etc) bond. Furthermore, in some cases an increase of the bond can be detrimental to the service behaviour of the material.

The object of the present paper, a summary of another more extensive work recently completed (3), is to show the current state of knowledge according to the studies and progresses so far achieved in connection with the microstructure of concrete, with especial emphasis on the microstructural characteristics of the cement paste-(aggregate, reinforcement, fibre, etc.) interface and their relationship with concrete properties.

\section{ORIGIN AND DEVELOPMENT OF THE MICROSTRUCTURE}

The cement paste is the result of a number of hydration reactions occurring when a given amount of cement is mixed with a limited amound of water. The major reactions so occuriring include: 


$$
\begin{aligned}
& 2 \mathrm{C}_{3} \mathrm{~S} \text { (alita) }+7 \mathrm{H} \rightarrow \mathrm{C}-\mathrm{S}-\mathrm{H}+3 \mathrm{CH} \\
& 2 \mathrm{C}_{2} \mathrm{~S} \text { (belita) }+5 \mathrm{H} \rightarrow \mathrm{C}-\mathrm{S}-\mathrm{H}+\mathrm{CH} \\
& \mathrm{C}_{3} \mathrm{~A}+3 \mathrm{C} \overline{\mathrm{S}} \mathrm{H}_{2}+26 \mathrm{H} \rightarrow \mathrm{C}_{6} \mathrm{AS}_{3} \mathrm{H}_{32} \\
& \mathrm{C}_{6} \overline{\mathrm{S}}_{3} \mathrm{H}_{32}+2 \mathrm{C}_{3} \mathrm{~A}+4 \mathrm{H} \rightarrow 3 \mathrm{C}_{4} \mathrm{~A} \overline{\mathrm{S}} \mathrm{H}_{12}
\end{aligned}
$$

Estas reacciones de hidratación comienzan inmediatamente, incluso de modo violento, disminuyendo su actividad en un corto período de tiempo. Posteriormente, la velocidad de hidratación experimenta un nuevo incremento, seguido ya por el fraguado de la pasta, en donde la movilidad del sistema hasta ese momento plástica, se pierde. Este esquema así descrito puede ser visualizado en la figura 1 (4) que representa la evolución calorífica respecto al tiempo del proceso de hidratación del cemento portland.

El desarrollo de la estructura de los productos de hidratación se puede dividir en tres etapas fundamentales (5):

a) Etapa inicial: el foco de actividad está fundamentalmente concentrado en la superficie de los granos de cemento y en el agua de mezcla más cercano a estas superficies.

b) Etapa intermedia: los productos de hidratación se depositan en el interior de los espacios iniciales rellenos de agua, y comienza a conformarse una estructura coherente.

c) Etapa final: el esqueleto estructural se rellena con productos de hidratación que provienen del interior de las fases de cemento originales. Un esquema de estas tres etapas puede ser visualizado en la figura 2.

Las dos primeras etapas se dan durante las primeras horas de hidratación, mientras que la última comprende la mayoría del período real de hidratación activa.

$$
\begin{gathered}
2 C_{3} S \text { (alite) }+7 H \rightarrow C-S-H+3 C H \\
2 C_{2} S \text { (belite) }+5 H \rightarrow C-S-H+C H \\
C_{3} A+3 C \bar{S} H_{2}+26 H \rightarrow C_{6} A \bar{S}_{3} H_{32} \\
C_{6} A \bar{S}_{3} H_{32}+2 C_{3} A+4 H \rightarrow 3 C 4 A \bar{S} H_{12}
\end{gathered}
$$

These hydration reactions begin rapidly, even violently, and their activity decreases within a short period. Later, the hydration rate experiences a new increase, followed by the setting of the paste, where the mobility of the system, plastic up to that moment, disappears. The pattern described may be seen in figure 1 (4); this figure shows the caloric evolution with time of the hydration process for Portland cement.

The hydration products structural development can be divided in three basic stages (5):

a) Intial stage: the focus of activity is basically centered in the cement grains surface and in the mix water closest to these surfaces.

b) Intermediate stage: The hydration products are deposited inside the previously water-filled spaces and a cohesive structure begins to form.

c) Final stage: The structural skeleton is filled with the hydration products from within the original cement phases. A schematic representation of the three stages can be seen in figure 2 .

The first two stages occur during the initial hours of the hydration process while most of the last stage depends on the actual period of active hydration.

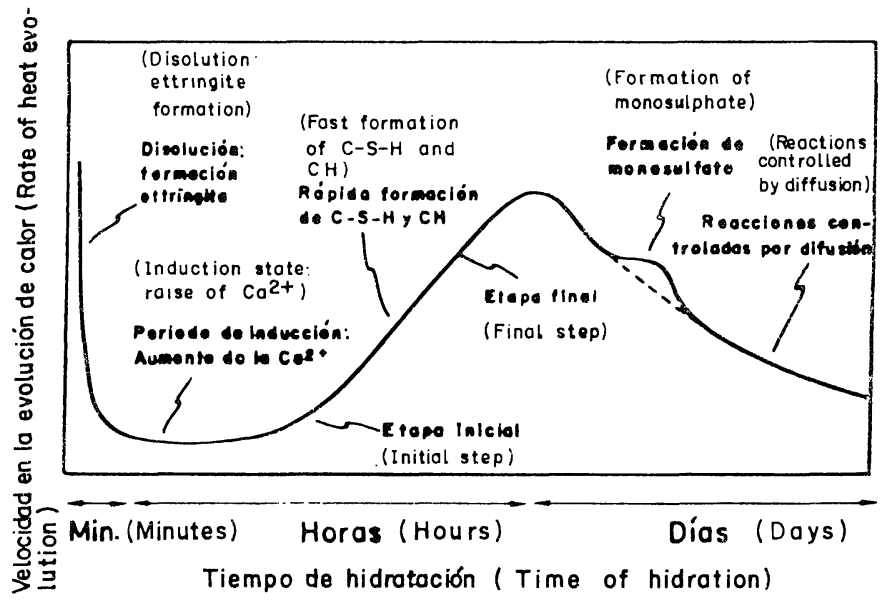

Fig. 1. Evolución del calor en la hidratación del cemento portland.

Fig. 1. - Heat evolution in Portland cement hidration. 

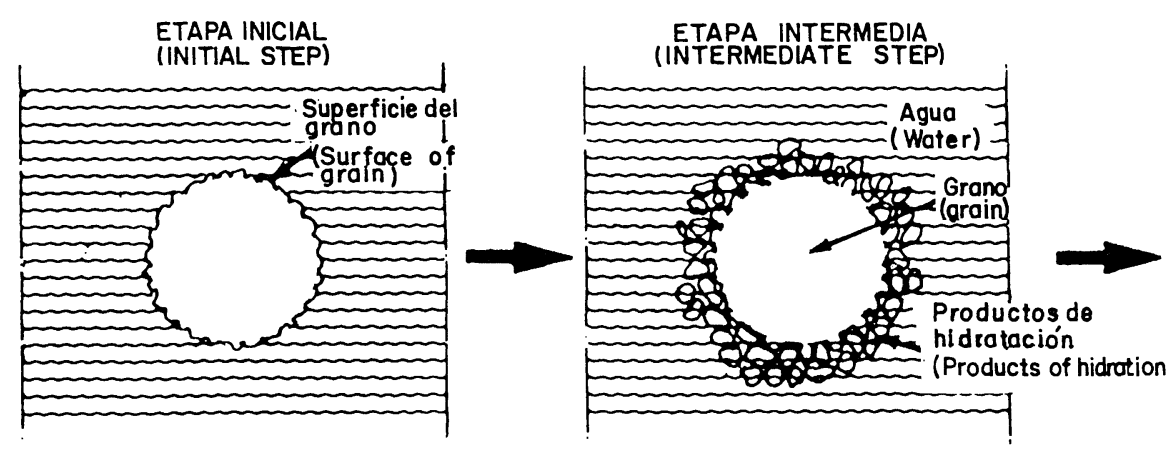

Fig. 2.-Etapas hidratación.

El desarrollo de la microestructura que concierne a la deposición de productos de hidratación en los espacios capilares y entre los granos de clínker es el siguiente (5): Inicialmente fibras de C-S-H y varillas de ettringita se complementan rápidamente con cristales de $\mathrm{CH}$; entonces empiezan a aparecer zonas de C-S-H tipo II y las cortezas adyacentes empiezan a enredarse unas con otras. Los planos delgados de $\mathrm{CH}$ crecen y se hacen gruesos y empieza a observarse la característica capa de $\mathrm{Ca}(\mathrm{OH})_{2}$. Posteriormente, comienza la deposición de gel C-S-H tipo III que se superponen sobre los depósitos masivos de $\mathrm{CH}$, encajándose unos con otros, con los que se dificulta la posibilidad de distinguir los contornos de las partículas y especialmente si la relación a/c es baja.

Estos procesos descritos varían en los detalles microestructurales de un sitio a otro dentro de la misma pasta. Además, la velocidad de deposición de los productos está condicionada por el cemento usado y las condiciones ambientales locales.

En definitiva, la extension a la cual la morfología adquiere madurez no es con frecuencia uniforme sobre la totalidad de la pasta; consecuentemente en un momento dado pueden coexistir en una misma pasta varias morfologías (6).

\section{MICROESTRUCTURA DE LA INTERFASE}

Sin duda, la zona más importante de la microestructura de la pasta de cemento en el hormigón, es la región próxima a la superficie de contacto con los áridos. La influencia de esta zona en el comportamiento del hormigón es considerable; existiendo en la literatura un gran número de trabajos que pretenden definir sus características.

Otras interfases de interés en el hormigón pueden ser las formadas alrededor de los aceros en los hormigones armados, y las que rodean a las fibras en los hormigones reforzados.
Fig. 2. - Hydration stages.

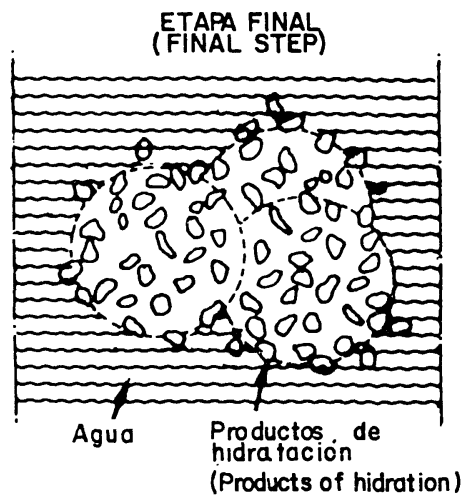

The development of the microstructure involving the deposition of hydration products into the capilar spaces and amongst the clinker grains clinker is as follows ${ }^{5}$ ): Initially $\mathrm{C}-\mathrm{S}-\mathrm{H}$ fibres and ettringite rods are rapidly complemented with $\mathrm{CH}$ crystals; then type II C-S-H areas being to appear and the adjacent crust start meshing with each other. The thin $\mathrm{CH}$ planes expand, become thicker and the characteristic $\mathrm{Ca}(\mathrm{OH})_{2}$ layer can then be observed. Deposition of type III C-S-H gel comences thereafter overlaying the masiv $\mathrm{CH}$ deposits, becoming interlocked and thus making it difficult to identify the particle contours, particularly when the $w / c$ ratio is low.

The processes described vary in microstructural details depending on the paste area considered. In addition, the products deposition rate is influenced by the type of cement used and the local environmental conditions.

In short, the extent to which morphology reaches maturity is not often uniform across the entire paste; consequently, several different morphologies can coexist at a given time within the same paste (6).

\section{INTERFACE MICROSTRUCTURE}

Without doubt, the most important area in the microstructure of the cement paste within the concrete is around the contact surface with the aggregate. The influence of this area on concrete behaviour is considerable and a good number of works in the literature attempt to describe its characteristics.

Other concrete interfaces of interest can be those formed around the rods in steel-reinforced concretes and those surrounding the fibers in fiber reinforced concretes. 
A continuación, se va a desarrollar preferentemente aquellos aspectos relativos a las uniones o interfases originadas entre la pasta de cemento y los áridos, aunque también se va a incidir en las otras interfases mencionadas.

\subsection{Microestructura de la interfase árido- pasta de cemento}

\subsubsection{Reacciones químicas en la interfase árido- pasta de cemento}

Algunas reacciones químicas pueden producirse entre el árido y la pasta de cemento y, dependiendo de cada caso, estas reacciones pueden mejorar ó empeorar la unión entre los dos componentes.

\section{- Reacción árido-álcalis.}

Ciertos fenómenos de expansión, fisuración y pérdidas de resistencia, elasticidad y durabilidad producidas en el hormigón pueden ser consecuencia de la reacción entre los iones alcalinos procedentes del cemento portland (o de otras fuentes) y los componentes silíceos que se pueden encontrar en los áridos. En la literatura moderna, este fenómeno es conocido con el nombre de reacción árido-álcalis $(7,8)$.

Ciertas rocas de naturaleza silícea con elevado contenido en sílice amorfa reaccionan con los álcalis del cemento, dando lugar a la formación de geles de sílice que, generalmente, tienen una acción osmótica, en presencia de agua, y que por absorción de ésta aumentan de volumen y provocan importantes presiones disruptivas.

El esquema general del proceso ha sido establecido por Plum y Col (9) de acuerdo con la siguiente reacción:

$$
\begin{aligned}
& \mathrm{SiO}_{2}+\mathrm{NaOH}+\mathrm{Ca}(\mathrm{OH})_{2}+\mathrm{H}_{2} \mathrm{O} \rightarrow \\
& \rightarrow n_{1} \mathrm{Na}_{2} \mathrm{O} \cdot \mathrm{n}_{2} \mathrm{CaO} \cdot \mathrm{n}_{3} \mathrm{SiO}_{2} \cdot \mathrm{n}_{4} \mathrm{H}_{2} \mathrm{O}
\end{aligned}
$$

En el caso de los áridos de naturaleza dolomítica, la dedolomitización de dichos áridos, por reacción con disoluciones alcalinas, produce la neoformación de brucita, $\mathrm{Mg}(\mathrm{OH})_{2}$, y una regeneración de hidróxido alcalino, lo que puede dar lugar a una continuidad del proceso, de acuerdo con las siguientes reacciones:

$$
\begin{gathered}
\mathrm{CaMg}\left(\mathrm{CO}_{3}\right)_{2}+\underset{+\mathrm{NaOH}}{+} \rightarrow \mathrm{Na}_{2} \mathrm{CO}_{3} \\
\mathrm{Na}_{2} \mathrm{CO}_{3}+\mathrm{Ca}(\mathrm{OH})_{2}+\mathrm{CaCO}_{2}+ \\
\rightarrow \mathrm{CaCO}_{3}+2 \mathrm{NaOH}
\end{gathered}
$$

Otros factores, que aparte de la naturaleza mineralógica y/o petrográfica de los áridos,
We will deal next in preference with the aspects involving the bonds or interfaces occurring between the cement paste and the aggregates, although we will also touch on the other mentioned interfaces.

\subsection{Microstructure of the Aggregate-Cement Paste Interfase}

\subsubsection{Chemical Reactions in the Aggregate- Cement Paste Interfase}

Several chemical reactions can occur between the aggregate and the cement paste and, depending on the particular case, these reactions may improve or worsen the bond between both components.

\section{- Aggregate-Alkali Reaction}

Some phenomena of expansion, fissuring and strength, elasticity and durability loss occurring in concrete can be the result of a reaction between alkaline ions from the Portland cement (or other sources) and the silica components that may be found in the aggregate. In current literature this phenomenon is known as aggregate-alkali reaction $(7,8)$.

Some rocks of a siliceous nature with a high content of amorphous silica, react with the alkalis in cement causing the formation of siliceous gels which, as a rule, experience an osmotic reaction in the presence of water and, through water absorption, increase in volume giving raise to important disruptive pressures.

The overall process pattern has been given by Plum et al. (9) in accordance with the following expression:

$$
\underset{\rightarrow n_{1} \mathrm{Na}_{2} \mathrm{O} \cdot n_{2} \mathrm{CaO} \cdot n_{3} \mathrm{SiO}_{2} \cdot n_{4} \mathrm{H}_{2} \mathrm{O}}{\mathrm{SiO}_{2}+\mathrm{NaOH}}
$$

In the case of dolomitic type aggregates, the dedolomitisation of such aggregates through reaction with alkaline solutions causes a neoformation of brucite, $\mathrm{Mg}(\mathrm{OH})_{2}$, and a regeneration of alkaline hydroxide, which can provide process continuity, as per the following reactions:

$$
\begin{gathered}
\mathrm{CaMg}\left(\mathrm{CO}_{3}\right)_{2}+\underset{2 \mathrm{NaOH}}{+} \rightarrow \mathrm{Mg}(\mathrm{OH})_{2}+\mathrm{CaCO}_{3}+ \\
+\mathrm{Na}_{2} \mathrm{CO}_{3} \\
\mathrm{Na}_{2} \mathrm{CO}_{3}+\mathrm{Ca}(\mathrm{OH})_{2} \rightarrow \mathrm{CaCO}_{3}+2 \mathrm{NaOH}
\end{gathered}
$$

Other factors with, aside from the mineralogical and/or petrographical nature of the aggregates, 
también influyen en la reacción árido-álcalis son (10):

- Contenido y tamaño de los áridos reactivos: Si el contenido de áridos es superior al $35 \%$ la reacción no se produce, ya que las partículas reactivas reducen rápidamente la concentración de álcalis, impidiendo la formación de un gel. Si el tamaño del árido es muy pegueño, la reacción se produce antes de la formación del gel, evitándose la degradación.

- Contenido de álcalis en la fase líquida del hormigón: El limite máximo de álcalis en el cemento, establecido por las distintas normas internacionales, oscila alrededor del $0,6 \%$ en $\mathrm{Na}_{2} \mathrm{O}$.

- Tiempo y humedad: Si no hay humedad, la reacción árido-álcalis es un fenomeno lento y prácticamente inofensivo. Sin embargo, si el agua penetra en el hormigón la reacción puede sufrir una notable aceleración y llevar a la estructura a su destrucción.

- Temperatura: el incremento de la temperatura acelara la reacción.

\section{- Reacción $\mathrm{Ca}(\mathrm{OH})_{2}$ - árido.}

La reacción entre $\mathrm{Ca}(\mathrm{OH})_{2}$ y determinados tipos de áridos (con arcillas y feldespatos en su composición mineralógica) da lugar a la formación de hidrogranates (alumino-silicato de cálcio hidratado), silicato cálcico y álcalis libres. Estos productos se disponen alrededor de los áridos disminuyendo la adherencia árido-pasta de cemento, lo que puede llegar a producir la destrucción de una estructura de hormigón.

Los factores que afectan a esta reacción son los mismos descritos para la reacción árido-álcalis.

\section{- Reacción $C_{3} A$ del clínker del cemento portland-árido.}

El $\mathrm{C}_{3} \mathrm{~A}$ reacciona con las piedras calizas utilizadas como árido, formando un monocarboaluminato de cálcio $\left(\mathrm{C}_{3} \mathrm{~A} \cdot \mathrm{CaCO}_{3} \cdot 11 \mathrm{H}_{2} \mathrm{O}\right)$. La cantidad de este compuesto en la pasta decrece con la distancia al árido y al disminuir la relación agua/cemento (11).

\subsubsection{Morfología de la interfase árido-pasta de cemento}

En la actualidad, es comúnmente aceptado que en las proximidades del árido se desarrolla una microestructura de la pasta de cemento (con un espesor de unos $50 \mu \mathrm{m}$ ), diferente a la del resto del volumen de la pasta, aun en ausencia de reacción. also have an influence on the aggregate-alkali reaction include (10):

- Contents and size reactive aggregates. If aggregate is supplied in a proportion higher than $35 \%$, reaction does not occur since the reactive particles rapidly reduce the alkali content preventing gel formation. If the aggregate size is too small, the reaction takes place after the gel has formed and degradation is then prevented.

- Alkali contents in the fluid stage of concrete: the maximum limit of alkalis in cement, as provided by several international standards, varies around $0.6 \%$ in $\mathrm{Na}_{2} \mathrm{O}$.

- Weather and humidity: In the absence of moisture, the aggregate-alkali reaction is slow and virtually safe. Nevertheless, if water penetrates the concrete, the reaction can experience a noticeable acceleration and lead to structural destruction of concrete.

- Temperature: The higher temperature, the quicker the reaction.

\section{$-\mathrm{Ca}(\mathrm{OH})_{2}$ agregate reaction}

The reaction between $\mathrm{Ca}(\mathrm{OH})_{2}$ and certain aggregate types (having clays and feldspars in their mineralogic composition) causes the formation of hydrogarnets (hydrated calcium aluminum-silicate), calcium silicate and free alkalis. These products arrange themselves around the aggregate reducing the cement pasteaggregate bond with the risk of causing the destruction of one concrete layer. The factors affecting this reaction are the same as the ones already described for the aggregate-alkali reaction.

\section{- From $\mathrm{C}_{3} \mathrm{~A}$ portland cement clinker- aggregate reaction}

The $C_{3} A$ reacts with the limestone used as aggregate to form a calcium monocarbo-aluminate $\left(\mathrm{C}_{3} \mathrm{~A} \cdot \mathrm{CaCO}_{3} \cdot 11 \mathrm{H}_{2} \mathrm{O}\right)$. The proportion of this compound in the paste decreases with the distance from the aggregate and with the reduction of the water/cement ratio (11).

\subsubsection{Morphology of the Aggregate-Cement Paste Interface}

It is now commonly accepted that a microstructure of the cement paste developes near the aggregate (with a thickness of some $50 \mu \mathrm{m}$ ) that is different from the rest of the paste body, even in the absence of a reaction. 
Esta zona de interfase árido-pasta se caracteriza por tener una relación a/c superior a la existente en el resto del volumen de la pasta, debido a efectos de exudación superficial en las caras del árido.

En estudios preliminares se denominó a esta zona como zona de transición o aura de transición. Se describe como una región que se extiende radialmente hacia afuera desde la superficie del árido y se introduce gradualmente en la pasta de cemento. Su espesor aproximado es de unos $50 \mu \mathrm{m}$, y destaca por su elevada porosidad y elevado contenido en $\mathrm{CH}$, que además posee una orientación preferencial con su eje c perpendicular a la superficie del árido (5).

Estudios posteriores $(12,13,14)$ han desvelado una microestructura más compleja de la interfase, cuyo desarrollo se resume a continuación, y puede ser visualizado en la figura 3 (15).

La pasta de cemento está formada por flóculos, cuasiesféricos de algunos cientos de micras, que son suficientemente fuertes como para resistir la dispersión por agitación mecánica mientras se amasa. En consecuencia, los granos de cemento se unen pobremente a las superficies de los áridos, dejando áreas extensas de alto contenido en agua tanto dentro de los flóculos como entre ellos.

Por la rápida sobresaturación de agua de iones $\mathrm{Ca}^{2+}$ y $\mathrm{OH}^{-}$se produce un depósito de una capa. de $\mathrm{CH}$ sobre la superficie del árido, de un espesor de 0,5 $\mu \mathrm{m}$. Esta capa de $\mathrm{CH}$ no aumenta de espesor con el tiempo, probablemente debido a la presencia de $\mathrm{SiO}_{2}$ disuelto en el agua. Esto produce el segundo depósito que es de gel fibroso de C-S-H, con fibras perpendiculares a la superficie, y de un espesor de 0,5 $\mu \mathrm{m}$ : A estas dos capas se le conoce con el nombre de película duplex.
This aggregate-paste interface area is characterised by a w/c ratio higher than that existing in the rest of the entire paste body owing to the effects of exudation and surface conditions in the aggregate faces.

In preliminary studies, this area was called transition zone or transition aura. It is described as a region extending outwardly from the aggregate surface and gradually penetrating the cement paste. Its approximate thickness is about $50 \mu \mathrm{m}$ and stands out because of its high porosity and high $\mathrm{CH}$ contents, aside from a preferential orientation of its $c$ axis perpendicular to the aggregate surface (5).

Later studies $(12,13,14)$ have revealed a more complex interface microstructure whose development is described next and can be seen in figure 3 .

The cement paste is formed by near-spherical flocules measuring a few hundreds microns, sufficiently strong to resist dispersion from mechanical agitation while mixing. Consequently, the cement grains are poorly bonded to the aggregate surface, leaving extensive areas with high water content, both within the flocules and amongst them.

Owing to the rapid oversaturation of $\mathrm{Ca}^{2+}$ and $\mathrm{OH}^{-}$ions in the water, a $\mathrm{CH}$ layer is deposited on the aggregate surface, some 0,5 $\mu \mathrm{m}$ in thickness. The thickness of this $\mathrm{CH}$ layes does not increase with time, probably due to the presence of $\mathrm{SiO}_{2}$ disolved in the water. This causes a second deposit which is the C-S-H fibrous gel, with fibers arranged perpendicularly to the surface and a 0,5 $\mu m$ thickness. This double layer is known as duplex film.

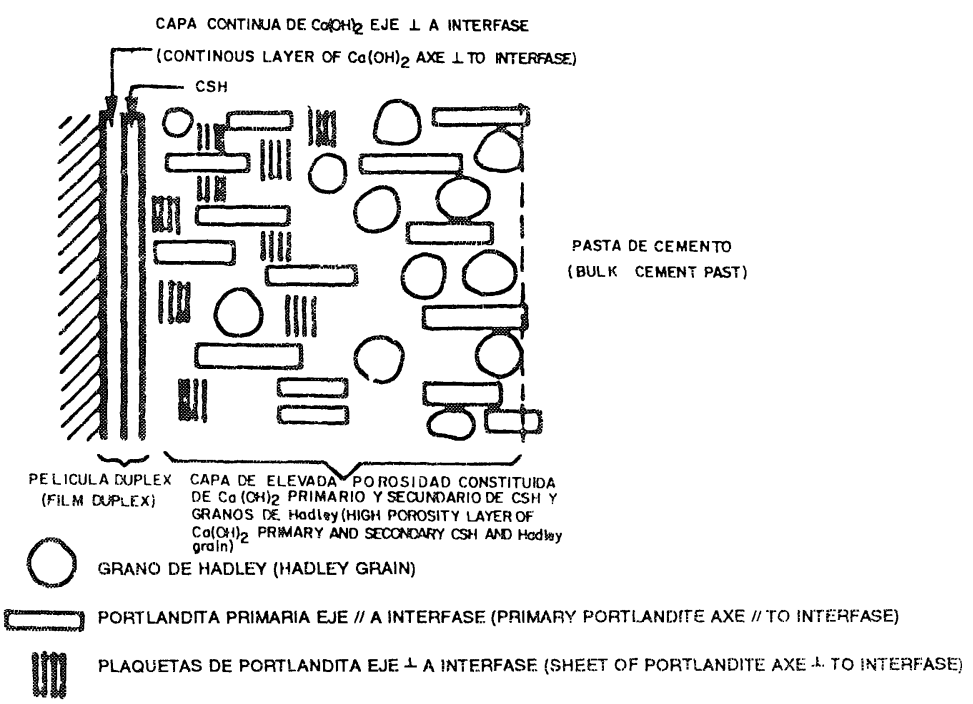

Fig. 3.-Representación esquemática de la interfase áridopasta de cemento según J. C. Maso (ref. 12).
Fig. 3.-Schematic representation of the aggregate-cement paste interface. J. C. Maso (Ref.12). 


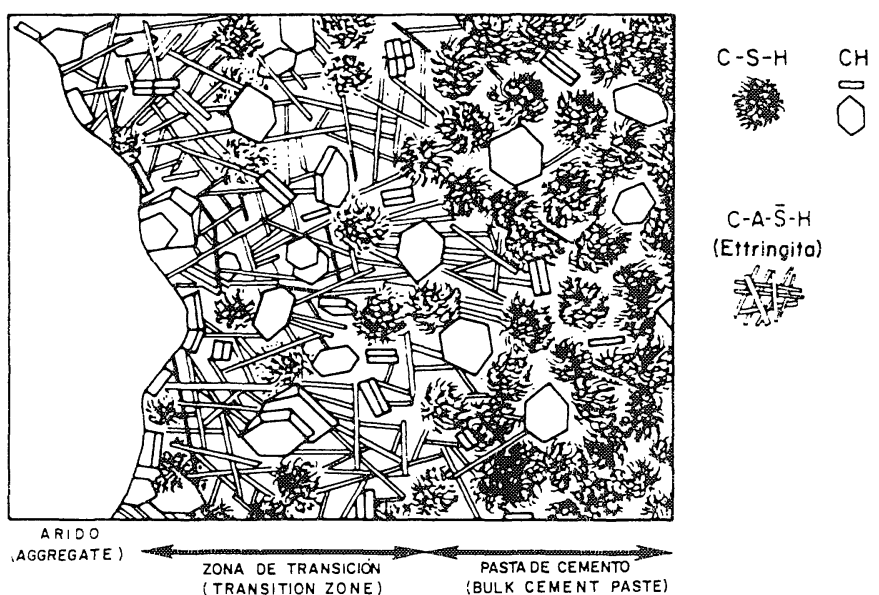

Fig. 4.-Representación esquemática de la interfase áridopasta de cemento según Monteiro y Metha (ref. 15).

Después de 2 ó 3 días, una segunda capa de $\mathrm{CH}$, con un espesor de $3 \mu \mathrm{m}$, se deposita en el Duplex. Son cristales de $\mathrm{CH}$ apilados de modo paralelo con su eje orientado perpendicularmente a la citada película. Al mismo tiempo, se generan cristales más largos y tubulares de $\mathrm{CH}$ de eje paralelo a la película duplex. Estos cristales de $\mathrm{CH}$ se extienden hacia la pasta y sólo gradualmente dan lugar a la microestructura usual del gel de C-S-H y CH de la pasta.

El espesor de la zona de transición no cambia prácticamente con el tiempo, ya que sólo depende del espesor de la capa del líquido que inicialmente mojaba al árido.

Lo expuesto hasta el momento es un resumen de lo que algunos investigadores sostienen; sin embargo, Monteiro y Metha (15) indican que la formación de ettringita en las zonas próximas al árido juega un papel destacado en el desarrollo microestructural de la interfase.

En la figura 4 puede observarse la representación esquemática de la morfologia de la interfase árido-pasta de cemento propuesta por los autores anteriormente mencionados.

\subsubsection{Resistencia de la Interfase y su Influencia en las Propiedades del Hormigón}

La resistencia intrínseca de la zona de transición depende, principalmente, de los siguientes aspectos (12):

- Volumen y tamaño de poros: A primeras edades, el volumen y tamaño de los poros en la zona de transición es mayor que en el resto de la pasta de cemento, siendo, por lo tanto, la interfase más débil desde el punto de vista resistente. A mayores edades, sin embargo, la resistencia de la zona de transición puede aumentar y superar incluso a la de la pasta de cemento.
Fig. 4. Schematic representation of the aggregate-cement paste interface. Monteiro and Metha (Ref. 15).

After two or three days, a second $3 \mu \mathrm{m}$ thick $\mathrm{CH}$ layer is deposited on the duplex layer. These are $\mathrm{CH}$ crystals piled in parallel and with their axis oriented perpendicularly to the duplex film. Longer and tubular in shape $\mathrm{CH}$ crystals are generated simultaneously with their axis parallel to the duplex film. These $\mathrm{CH}$ crystals extend themselves inside the paste and so, they gradually generate the usual $\mathrm{C}-\mathrm{S}-\mathrm{H} \mathrm{gel}$ and $\mathrm{CH}$ microstructure of the paste.

The thickness of the transitional area does not virtually change with time, as it is only dependent on the thickness of the liquid layer initially wetting the aggregate.

What has been so far discussed (15) is a summary of what some researches maintain; nonetheless, Monteiro and Metha (15) suggest the ettingite formation in the areas close to the aggregate plays an important part in the microstructural development of the interface.

A schematic representation of the aggregatecement paste interface morphology, as proposed by the above mentioned authors, can be seen in figure 4.

\subsubsection{Interface Strength and its Influence on Concrete Properties}

The intrinsic strength of the transitional area depends particularly on the following features (12):

- Pore number and size: In early stages, the number and size of the pores in the transitonal area are greater than in the rest of the cement paste and, therefore, the interface is weaker from the strength standpoint. But in later stages, the transitional area strength can increase and even surpass that of the cement paste itself. 
- Contenido y orientación de los cristales de $\mathrm{CH}$ : La interfase es una zona muy rica en cristales grandes de $\mathrm{CH}$, que son menos adherentes y resistentes que los de C-S-H. La orientación preferencial de los cristales de $\mathrm{CH}$ favorece la propagación de microfisuras.

- Presencia de microfisuras: La cantidad de microfisuras presentes depende de los siguientes factores:

- Tamaño y granulometría del árido.

- Contenido en cemento.

- Relación a/c.

- Condiciones de curado.

- Humedad ambiental.

- Historia térmica del hormigón.

Por estas tres razones, y muy especialmente por la última, la interfase árido-pasta de cemento es la zona más frágil del hormigón endurecido. La presencia de la zona de transición hace que el hormigón se fracture a niveles de carga considerablemente más bajos que las resistencias de cualquiera de sus otros dos componentes principales (pasta de cemento y árido (2).
- Contents and orientation of $\mathrm{CH}$ crystals: The interface is an area rich in large $\mathrm{CH}$ crystals, less adhesive and resistant than $\mathrm{C}-\mathrm{S}-\mathrm{H}$, ones. The preferential orientation of these $\mathrm{CH}$ crystals favours the propagation of microfissures.

- Presence of microfissures: the quantity of microfissures present depends on the following factors:

- Aggregate size and grading

- Cement contents;

- w/c ratio;

- Curing conditions;

- Environmental humidity;

- Thermal history of concrete.

Owing to the three above reasons, particularly the last one, the aggregate-cement paste interface is the weakest area of hardened concrete. The presence of the transition area causes the concrete to fracture at loading levels considerably lower than the strength of any of the other two major concrete components [cement paste and aggregate (2)].
(2) $50 \%$ DE RESISTENCIA ÚLTIMA

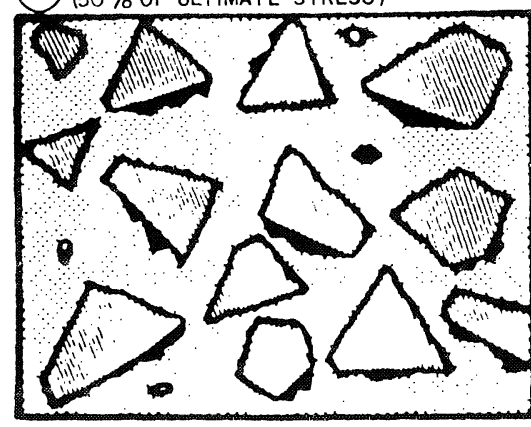

(1) $30 \%$ DE RESISTENCIA ÚLTIMA
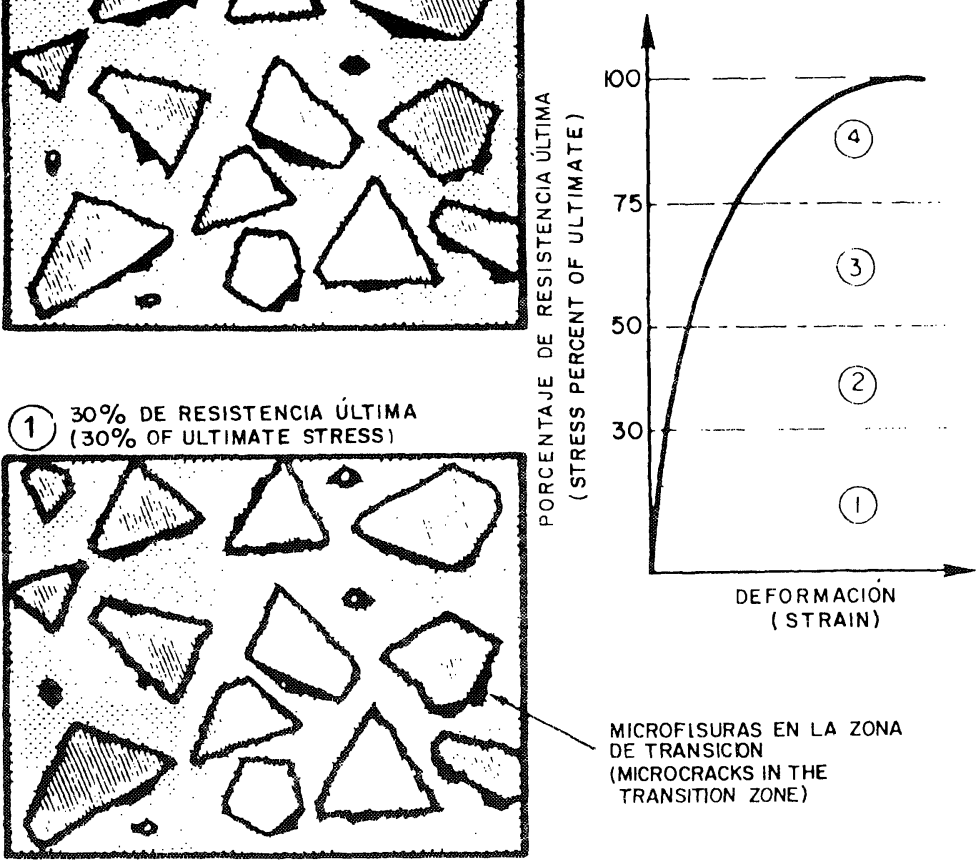

4) FRACTURA
(FAILURE STRESS)

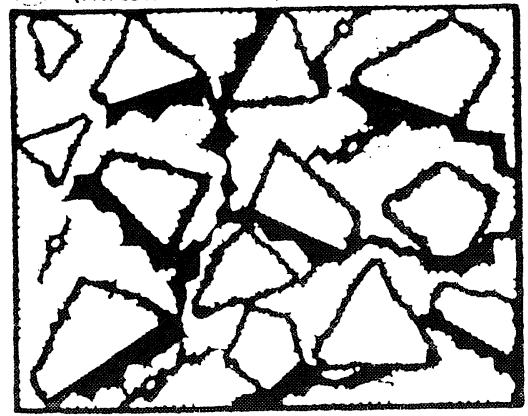

(3) $75 \%$ DE RESISTENCIA ÚLTIMA

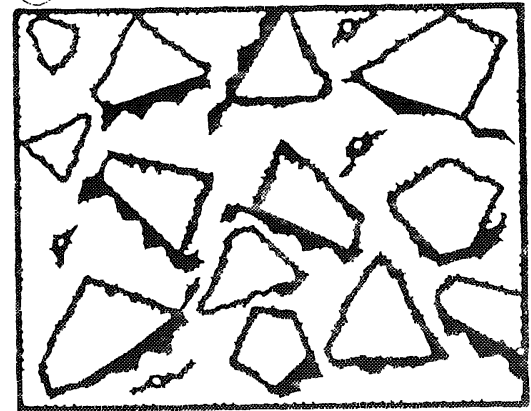

Fig. 5.----Representación esquemática sobre el comportamiento carga-deformación en el hormigón bajo compresión uniaxil.
Fig. 5.- Schematic representation of the sress-strain behaviour of concrete under single-axial compression. 
No son precisos niveles de energía muy elevados para propagar las fisuras o microfisuras ya existentes en la zona de transición.

En la figura 5 (16) aparecen esquematizadas cuatro etapas que describen el comportamiento del hormigón sometido a una carga. Por debajo de un $30 \%$ de la resistencia última (etapa I) las microfisuras de la zona de transición (ya existentes previamente) permanecen estables, haciendo que la curva carga-deformación sea lineal.

Por encima de este $30 \%$ de la resistencia última, y como consecuencia del incremento de la carga aplicada, las microfisuras de la zona de transición aumentan en longitud, anchura y número. Esto conlleva un incremento de la relación carga/deformación que provoca que su correspondiente curva se desvíe de una línea recta (etapa 2). Con valores próximos al $50 \%$ de la resistencia última, el sistema de microfisuración de la zona de transición es aún estable, y se empiezan a producir la primeras fisuras en la matriz.

Alrededor del $75 \%$ de la resistencia última (etapa 3) no sólo el sistema de fisuras de la zona de transición se hace inestable sino que también se produce la proliferación y propagación de las fisuras en la matriz, haciendo que la curva carga/deformación se aleje aún más de la línea recta inicial.

Por encima del $75 \%$ (etapa 4) al incrementar la carga se producen unas deformaciones muy intensas que indican que el sistema de fracturas se está haciendo continuo, debido a la rápida propagación de las fisuras existentes tanto en la zona de transición, como en la matriz.

Se necesita una energía considerable para la formación y propagación de las fisuras de la matriz bajo cargas de compresión; mientras que bajo cargas de tracción, las fisuras se propagan mucho más rápidamente a menores niveles de energía. Esta es la razón por la que el hormigón es frágil a tracción y robusto a compresión.

\subsection{Microestructura de otras interfases de interés}

\subsubsection{Microestructura de la interfase acero-pasta de cemento}

La elevada alcalinidad del electrolito encerrado en los poros del hormigón ( $\mathrm{pH}>12$ ) hace que las armaduras embebidas en hormigón se encuentren en estado de pasividad.

Esta pasividad es debida a la formación sobre la superficie del metal de una fina capa (20-200 Å)
Very high levels of energy are not necessary to propagate the fissures of microfissures already existing in the transitional area.

Figure 5 (16) shows four schematic stages describing the behaviour of concrete under load. Below $30 \%$ of the ultimate strength (stage 1) the microfissures in the transition area (previously existing) remain stable, producing a linear strain-stress curve.

Above that $30 \%$ ultimate strength as a result of the application of a higher load, the transitional area microfissures increase in length, width and number. This brings about an increase of the strain stress ratio causing in turn the curve to deviate from the straight line (stage 2). With ultimate strength values close to $50 \%$, the microfissure system in the transitional area is still stable and the first fissures in the matrix begin to appear.

At about $75 \%$ ultimate strength (stage 3) not only the fissuring system in the transition area becomes unstable, but also fissures proliferate and propagate through the matrix turning the strain/stress curve farther away from the initial straight line.

Above $75 \%$ of ultimate strength (stage 4), as the load is increased, deep strains appear indicating the fracture system is becoming continuous owing to the rapid propagation of the fissures existing both in the transition area and in the matrix.

A considerable amount of energy is required for fissures to be formed and propagated in the matrix under compressive loads while, under traction loads, fissures propagate much more rapidly at lower energy levels. This explains why concrete is weak under traction and strong under compression.

\subsection{Microstructure of Other Interesting Interfaces}

\subsubsection{Microstructure of the Steel-Cement Paste Interface}

The high alkalinity of the electrolite entrained in concrete pores ( $\mathrm{pH}>12$ ) causes the concreteembedded reinforcements to be in a passive state.

This passivity is due to the formation of a thin (20200 A) water-impervious, highly protective layer of 
impermeable y altamente protectora constituida por óxidos de $\mathrm{Fe}\left(\mathrm{Fe}_{2} \mathrm{O}_{3}\right.$ y $\left.\mathrm{Fe}_{3} \mathrm{O}_{4}\right)$ que lo preserva indefinidamente (mientras no cambien las características físicas o químicas del hormigón) de cualquier signo de corrosión.

Tras esta reacción inicial no parece que ocurra ninguna otra interacción entre las armaduras y la pasta de cemento (en ausencia de agresivos) por lo qúe las uniones entre ambas fases son débiles.

Sin embargo el recubrimiento galvanizado de las armaduras en contacto con la pasta de cemento reacciona formando inicialmente $\mathrm{ZnO}$ ó $\mathrm{Zn}(\mathrm{OH})_{2}$ y desprendiendo hidrógeno gaseoso, que posteriormente se transforma en hidroxizincato de calcio produciendo una capa continua, homogénea y adherente que aisla el metal del medio preservándolo de su ataque (17).

La formación de esa capa de hidroxizincato parece tener efectos positivos, no sólo por su misión protectora irente a la corrosión, sino porque fortalece la unión acero galvanizado-pasta de cemento (18).

La microestructura de la zona de transición formada alrededor de los aceros, está constituida principalmente por cristales de portlandita.

En contacto directo con los aceros se desarrolla una capa de cristales de $\mathrm{CH}$ de espesor variable (pero nunca inferior a $1 \mu \mathrm{m}$ ) con el eje $\mathrm{C}$ orientado en sentido perpendicular al acero. La capa de portlandita no es continua ya que también so desarrollan algunas áreas de C-S-H.

Una representación esquemática de esta interiase puede ser visualizada on la figura 6 .

La microestructura de la zona de transición formada alrededor de fibras de acero ha sido esiudiadia por Bentur y col. (19). Estos estudios han evidenciado que la correspondiente interfase presenta unas características comunes a las
$\mathrm{Fe}$ oxides $\left(\mathrm{Fe}_{2} \mathrm{O}_{3}\right.$ and $\left.\mathrm{Fe}_{3} \mathrm{O}_{4}\right)$ on the metal surface which indefinitely prevents (if the concreie physical and chemical characteristics remain unchanged) the appearance of any signs of corrosion.

No interaction between the reinforcement and the cement paste (in the absence of aggressive products) seems to occur after this initial reaction.

\section{However, the galvanised coating of the} reinforcement reacts in contact with the cement paste, initially forming $\mathrm{ZnO}$ or $\mathrm{Zn}(\mathrm{OH})_{2}$ and releasing gaseous hydrogen that later is changed into calcium hydroxyzincate creating a continuous, homogeneous and adhesive layer to insulate and protect the metal from the aggressive action of the surrounding medium.

The formation of this layer of hydroxyzincate seems to have possitive effets, not only due its protective role against corrosion, but also because it strengthens the galvanised steel-cement paste bond (18).

The microstructure of the transition area formed around the steel is mainly constituted by portlandite crystals.

A yariable thickness (but never under $1 \mu \mathrm{m}$ ) layer of $\mathrm{CH}$ crystal is developed in direct contact with the steel with its $c$ axis oriented perpendicularly relative the steel. The layer of portlandite is continuous as some $C-S-H$ areas also develope.

A schematic representation of this interface can be seen in figure 6.

The microstructure of the transitional area formed around the steel fibers has been studied by Bentur et al. These siudies have shown that the relevant interiaco presenis common characierisijics with those developed in areas

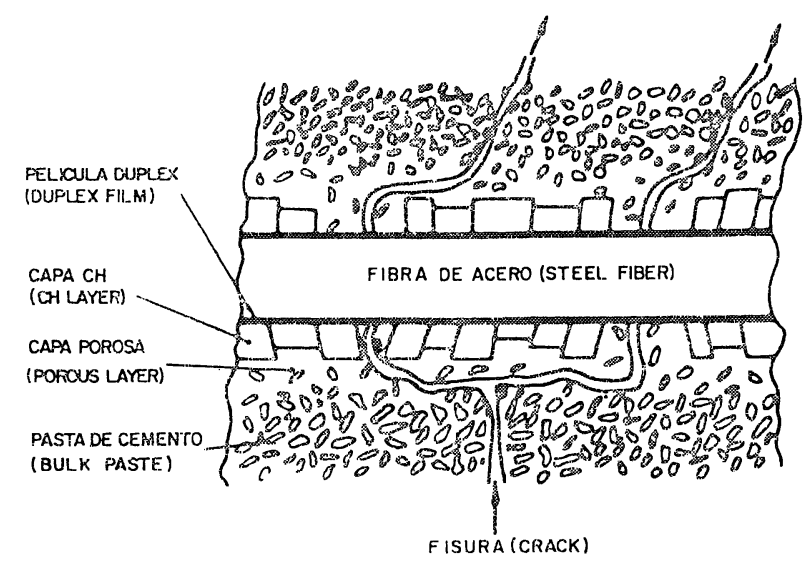

Fig. 6.-Representación esquemática interfase acero-pasta de cemento.
Fig. 6. Schematic representation of the steel-cement paste interfase. 
desarrolladas en las zonas próximas a los áridos. Aparece la película duplex que está rodeada por una zona de 10-30 $\mu \mathrm{m}$ de espesor y muy rica en cristales de $\mathrm{CH}$ con su eje $\mathrm{C}$ orientado perpendicularmente al acero. A continuación de esta extensa capa de $\mathrm{CH}$, estos autores identifican otra de gel C-S-H y de elevada porosidad, que es la principal causante de los fenómenos de fisuración en esta interfase. El porcentaje de portlandita y su orientación preferencial disminuye al aumentar la distancia a la fibra. En la zona de transición el contenido en $\mathrm{Ca}(\mathrm{OH})_{2}$ es entre un $20-40 \%$ superior al del resto del volumen de la pasta. Así mismo, la zona de alta porosidad puede extenderse hasta unas 100 $\mu \mathrm{m}$. En lo que a la microestructura de la interfase acero galvanizado-pasta de cemento se refiere, conviene mencionar que la interfase zinc-pasta de cemento, estudiada por Arliquie (18) y otros, presenta importantes diferencias tanto en evolución como en constitución, respecto de la interfase acero-pasta de cemento.

Dichos autores encuentran a las 24 horas una capa de $1 \mu \mathrm{m}$ de espesor constituida fundamentalmente por hidroxizincato cálcico, que recubre extensamente la superficie del zinc. Encuentran así mismo óxido de zinc en pequeña cantidad y trazos de ettringita. La presencia de hidróxido cálcico no es detectada hasta una distancia de $100 \mu \mathrm{m}$ desde la superficie del metal encontrando sin embargo cantidades de cemento anhidro superiores a las existentes en la masa de pasta de cemento. Transcurridos 1 ó 3 meses (la interfase no parece variar), se observa la existencia de una capa de 3-4 $\mu \mathrm{m}$ de espesor constituida fundamentalmente por hidroxizincato cálcico, pero conteniendo también ettringita en proporción mediana y trazas de hidróxido cálcico y óxido de $\mathrm{Zn}$. Más allá de esta capa se detecta una zona rica en hidróxido cálcico conteniendo ettringita en proporciones medianas e hidroxizincato cálcico también en mediana proporción hasta una distancia de $7 \mu \mathrm{m}$.

La adherencia acero-pasta de cemento permite que las tensiones puedan ser transferidas a través de la interfase. Estas tensiones son fundamentalmente tracción y cortante. Se ha comprobado que la adherencia de la interfase acero-pasta aumenta al disminuir la relación agua/cemento, y al prolongarse el tiempo de curado y compactación (20), (21).

En el caso de armaduras galvanizadas, las reacciones antes comentadas afectan de modo diverso la adherencia armadura/hormigón. Así, el hidrógeno gaseoso desprendido en las primeras horas en cantidad variable, dependiendo de factores tales como el pH de la fase acuosa del hormigón o de su contenido en cromatos, puede quedar aprisionado en forma de burbujas gaseosas en la interfase armadura/hormigón disminuyendo el área afectiva de contacto entre close to the aggregates. The duplex film appears here surrounded by a 10-30 $\mu \mathrm{m}$ thick area, very rich in $\mathrm{CH}$ crystals and with the axis oriented perpendicular to the steel. Next to this extensive $\mathrm{CH}$ layer, these authors identified another highly porous C-S-H gel layer, the main culprint of the fissuring phenomena in this interface. The percentage of portlandite and its preferential orientation decreases as the distance from the fiber is increased. The $\mathrm{Ca}(\mathrm{OH})_{2}$ contents in the transition area is from $20 \%$ to $40 \%$ higher than in the rest of the paste body. Likewise, the high porosity area can extend as far as some $100 \mu \mathrm{m}$. After discussing the galvanised steel-cement paste interface microstructure, it should be mentioned that the zinc-cement paste interface, estudied by Arliquie et al (18), presents important differences relative the steel-cement paste interface, both in its evolution and its constitution.

These authors found after 24 hours a $1 \mu \mathrm{m}$ thick layer basically formed by calcium hydroxyzincate extensively covering the zinc surface. They also found small amounts of zinc oxide and traces of ettringite. The presence of calcium hydroxide is not detected up to a distance of $100 \mu \mathrm{m}$ from the metal surface, but instead quantities of anhydrous cement higher than those existing in the cement paste body were found. After 1 to 3 months elapsed (the interface did not seem to change) the existence of a 3-4 $\mu \mathrm{m}$ thick layer was observed. This layer is basically constituted by calcium hydroxyzincate, but also by ettringite in medium proportions as well as traces of calcium hydroxide and $\mathrm{Zn}$ oxyde. Beyond this layer, an area rich in calcium hydroxide was detected with medium amounts of ettringite and calcium hydroxyzincate in similar proportions, up to a distance of $7 \mu \mathrm{m}$.

The steel-cement paste adherence permits stresses to be transferred through the interface. These stresses are basically traction and shear forces. It has been verified that the adherence of the steel-cement paste increases as the water/cement ratio decreases and as the curing and compaction time is lengthened $(20,21)$.

Where the reinforcement is galvanised, the above discussed reactions affect the reinforcementconcrete adherence in a different way. Thus, the hydrogen released in the initial hours in variable quantities (depending on factors such as the $\mathrm{pH}$ of the aqueous phase of concrete or its cromate contents) can be caught in the form of gaseous bubbles in the reinforcement/concrete interface so reducing the effective contact area between both materials and, consequently, their ability to 
ambos materiales y, en consecuencia, la capacidad de transmisión de propiedades mecánicas. Sin embargo, la formación de cristales de hidroxizincato íntimamente imbricados a las fases del cemento "ancla" la armadura, efecto que se expresa en un aumento posterior $\theta$ importante de la adherencia alcanzándose valores incluso netamente superiores a los obtenidos con armaduras semejantes de acero desnudo.

Finalmente, indicar que el empleo de resinas como material protector de las armaduras, frente a la corrosión de las mismas en medios agresivos, tienen manifestaciones diversas en relación a la adherencia de la interfase aceromatriz. Por ejemplo, las resinas epoxi tienen un papel reforzante, mientras que las resinas de cloruro de vinilo manifiestan más propiedades negativas en relación al fortalecimiento del enlace.

\subsubsection{Microestructura de la interfase fibra-pasta de cemento}

La interfase entre las fibras tipo AR y la pasta de cemento ha sido estudiada detalladamente por Stucke y Majumdar (22). Estos autores consideran como factor crítico controlante de las propiedades del composite la densidad de la región interfacial dependiente a su vez del tiempo y de las condiciones de almacenaje. Así por ejemplo la interfase fibra-matriz de un composite mantenido durante 90 días en ambiente seco es muy similar a la que tiene ese mismo composite al cabo de 5 años. El área de contacto entre la. fibra y el cemento es relativamente pequeña lo que le da al composite una alta tenacidad. Por contra, un composite mantenido durante 5 años inmerso en agua tiene una interiase relativamente densa con una porosidad residual de casi cero, consecuentemente con una gran área de contacto y generando por tanto un material duro y frágil.

De cualquier manera, el desacuerdo existente en la literatura con respecto a la interfase fibra de vidrio-matriz cementicia es evidente y el punto de controversia más agudo se centra en si existe o no una película duplex en esta interfase. Algunos autores $(22,14,23)$ mencionan en sus trabajos la existencia de la película duplex; mientras que otros como por ejemplo Bentur (24) sostienen que cuando la distancia entre fibras es superior a 10 $\mu \mathrm{m}$ hay una gran cantidad de cristales de $\mathrm{CH}$, casi perpendiculares a la superficie de las fibras junto con "clusters" de C-S-H y ocasionalmente agujas de ettringita. Cuando el espacio entre fibras es inferior a $3 \mu \mathrm{m}$, muy poco o nada de material penetra entre las fibras. La estructura de la pasta de cemento en la región interiacial es en cualquier caso generalmente muy porosa debido a las elevadas relaciones agua-cemento que se utiliza. transfer mechanical properties. Nevertheless, the formation of hydroxyzincate crystals closely interlocked into the cement phases, "anchors" the reinforcement, an effect occurring at a later and important time of the adherence process, where values are reached clearly higher than those obtained in similar reinforcements of uncoated steel.

Lastly, we shall indicate that the use of epoxy resins to protect the reinforcement against corrosion when in an aggresive medium, show a different behaviour relative to the steel-matrix adherence. For example, epoxy resins play a strengthening part, whilst vinyl chloride resins show more negative properties regarding bond reinforcement.

\subsubsection{Microstructure of the Fibre-Cement Paste Interface}

The interface between AR type glass fiber and cement paste has been studied in detail by Stucke and Majumdar (22). These authors consider the density of the interface region as a critical, controlling factor of the composite properties, the density being in turn dependent on storage time and conditions. For example, the fibre-matrix interface of a composite stored in a dry environment for 90 days is quite similar to the interface of the same material after 5 years. The cement-fiber contact surface is relatively small, thus giving the composite great toughness. Conversely, a composite kept for 5 years immersed in water has a relatively dense interface with an almost zero residual porosity and, consequently, with a large contaci area that generates a hard and fragile material.

In any case, the discrepancy found in the literature in repect of the glass fiber-cement matrix interface is evident and the most controverted point focuses on whether or not a duplex film actually exists in this interface. Some authors (22, $14,23)$ say in their works a duplex film does exist, whilst others, such as Bentur (24) maintain that where the fiber separation is more than $10 \mu \mathrm{m}$, there is a large number of $\mathrm{CH}$ crystals almost perpendicular to the fiber surface, together with $C$ $S-H$ clusters and, occassionally, needlas of ettringite. Where the fiber separation is less than $3 \mu \mathrm{m}$, little or no material penetrates amongst fibers. At any rate, the structure of the cement paste in the interface region is generally highly porous owing to the high water/cement ratios used. 


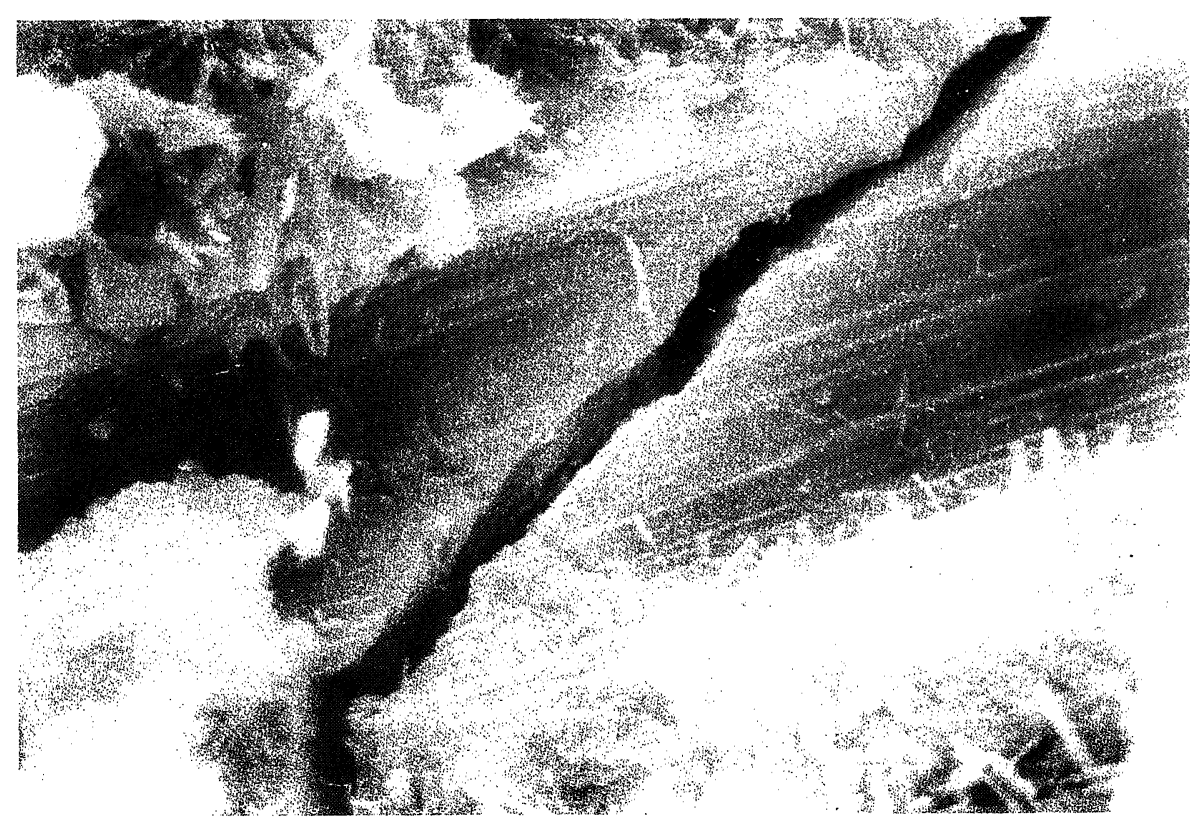

Fig. 7.-Interfase fibra acrilica-pasta.

Fig. 7.-Acrylic fibre-cement paste interfase.

Desde el punto de vista de su utilización como refuerzo de materiales de construcción las fibras acrílicas han sido ya probadas con éxito y tienen un mercado más o menos amplio y estable en el fibrocemento como sustitutas de algunos de los tipos de fibras de amianto. No obstante la aplicación de las fibras acrílicas en morteros y hormigones es algo de lo que todavía se sabe poco. En principio algunas de las propiedades inherentes a estas fibras apuntan un futuro prometedor para su uso como refuerzo de morteros y hormigones. Entre estas propiedades cabe destacar fundamentalmente su precio y su elevada resistencia al ataque químico por álcalis. Los datos que a continuación se van a exponer proceden de unas investigaciones que en la actualidad se están desarrollando en el ICCET.

Un examen llevado a cabo a través de la Microscopía Electrónica de Barrido sobre superficies de fractura de probetas de pasta de cemento reforzadas con fibras acrílicas ensayadas a tracción y a flexotracción y orientado a estudiar, tanto la propia morfología de las fibras de la superficie de fractura, como la zona de la matriz en contacto con la fibra, ha sacado a la luz los siguientes datos $(25,26)$ : La distribución de las fibras acrílicas, dependiendo del diámetro del filamento utilizado es más o menos homogénea; a mayor diámetro mayor homogeneidad.

En el caso de las fibras utilizadas con mayor diámetro se observa que han sufrido una fractura fundamentalmente longitudinal y frecuentemente con pérdida de material debido a la elongación sufrida por la fibra al ser sometida a los ensayos mecánicos.
The use of acrylic fibers have been succesfully tested as reinforcement for construction materials and enjoy a rather broad and stable market in fibre-cement manufacture as substitute of asbestos type fibers. Nonetheless, the application of acrylic fibers to mortars and concretes is not yet a well understood technique. In principle, some properties inherent to these fibers indicate a bright future as mortar and concrete reinforcement. Worth metioning among the most outstanding features of these fibers are, basicaly, their price and their high resistance to alkali aggression. The data presented next are from research work currently being carried out by ICCET.

An examination performed through Scanning Electron Microscopy on the fractured surfaces of acrylic fiber reinforced cement paste cores, tested under traction and flexotraction for the purpose of studying both the fiber own morphology in the fracture surface and the matrix area in contact with the fibers, have brought to light the following information $(25,26)$. The acrylic fibers distribution is more or less homogeneous, depending on the diameter of the filament used; the greater the diameter, the higher the homogenity.

It was observed that the larger diameter fibers used break along a basically longitudinal pattern, with frequent loss of material owing to the elongation experienced by the fiber during the mechanical tests. 
En la matriz cementicia de las superficies de fractura de las probetas estudiadas y reforzadas con las fibras de menor diámetro se puede ver la huella dejada por algunas fibras que, presumiblemente, han deslizado en el transcurso de los ensayos mecánicos. Estas huellas además tienen la particularidad de aparecer en mayor proporción en aquellas probetas con dosificación en fibras más elevada. El examen de la interfase fibra-matriz revela la existencia de grandes zonas lisas (no continuas) constituidas por grandes cristales de $\mathrm{Ca}(\mathrm{OH})_{2}$ acompañadas también de zonas con productos de hidratación del cemento (C-S-H, ettringita, etc.) (ver figura 7).

Finalmente, mencionar que las fibras de acero se obvian porque en realidad la contribución de ese tipo de fibras, y consecuentemente de su interfase con la matriz, a la conformación de la microestructura del material, no difiere prácticamente en nada con aquella microestructura ya descrita para el caso de los hormigones. armados y en definitiva con la interfase matriz-armadura.
The tracks left by some fibers that presumably slipped out of place during the mechanical tests can be seen in the cement matrix of the fracture surfaces in the test cores having smaller diameter fibers. These tracks also show a tendency to appear in higher numbers in cores with higher fiber proportions. The inspection of the fiber-matrix interface reveals broad (discontinuous) smooth areas formed by large $\mathrm{Ca}(\mathrm{OH})_{2}$ crystals, concomitant with areas of cement hydration products (C-S-H, ettringite, etc.) (see figure 7).

We shall mention in closing that steel fibers have been omitted in this discussion because, in actuality, the contribution of this type of fibers and, consequently, of the material microstructure configuration, is not different in any material respect from the microstructure already described for reinforced concrete and, in short, from the matrix-reinforcement interface.

\section{BIBLIOGRAFIA}

(1) MEHTA, P. K.: "Hardened cement paste-microestructure and its relationship to properties. VII Congr. Intern. Química del Cemento (Río de Janeiro) Vol. I, pp. 11-121 (1986).

(2) MEHTA, P. K.: "Concrete: structure, properties and materials". Prentice-Hall, Inc. Englewood Cliffs, New York, pp. 17-41 (1986)

(3) PUERTAS, F.; BLANCO, M. T.; PALOMO, A.: "Microestructura del hormigón. Influencia sobre las propiedades. Monografía, n. ${ }^{\circ} 398$, ICCET (CSIC) (1989).

(4) JAWED, L.; SKALNY, J.: "Structure and performance of cements". Charper 6. Ed. P. Bames. Applied Science publishers. pp. 237-317 (1983).

(5) DIAMOND, S.: "The microestructure of cement paste in concrete". VIII Congr. Intern. Química del Cemento (Río de Janeiro), Vol I, pp. 122-147 (1986).

(6) DIAMOND, S.: "Cement paste microestructure: an overview at several levels". Proc. Conf. Hydraulic Cement pastes: Their structure and properties. Sleffield, pp. 2-30 (1976).

(7) HADLEY, D. W.: "Alkali reactivity of dolomite carbonate rocks". Highway Research Board, 40, pp. $462-469$ (1961).

(8) DENT GLASSER, L. S.; KATAOKO, N.: "The chemistry of alkali aggregate reaction". Cem. Contcr. Res. Vol. II, pp. 1-9 (1981).

(9) PLUM, N. M.; POULSEN, E., IDORN, G. M.: "Preliminary survey of alkali reaction in concrete". Ingeniorum Int. Ed. Danemark, 2, pp. 26-32 (1958).

(10) SORIANO, J.: "Reacciones de interacción entre el árido y el cemento". Seminario: "Durabilidad del hormigón y de los materiales pétreos. Mecanismos de degradación". CEMCO-88 (1988).

(11) GRANDET, J.; OLLIVIER, S. P.: "Etude de la formation du monocarbonatoaluminate de calcium hydrate au contact d'un granulat calcaire dans un pâte de ciment portland". Cem. Concr. Res. Vol. 10, pp. 759-770 (1980).

(12) MASO, J. C.: "The bond between aggregate and hydrated cement paste". VII Congr. Intern. Química del Cemento. Vol. I, pp. VII-1/3 VII-1/15 (1980)

(13) STRUBLE, L.; SKALNY, J.; MINDESS, S.: "A review of the cement aggregate bond". Cem. Concr. Res., Vol. 10, pp. 277-286 (1980). 
(14) BARNES, B. D.; DIAMOND, S., DOLCH, W. L.: "The contact between portland cement paste and glass "aggregate" surfaces". Cem. Concr. Res. Vol. 8, pp. 233-244 (1978).

(15) MONTEINO, P. J. M.; MEHTA, P. K.: "Transicion zone between aggregate and type K expansive cement". Cem. Concr. Res. Vol. 16, pp. 111-114 (1986).

(16) GLUCKLICH, L.: Proc. Int. on the Structure of Concrete, Cement and Concrete Association, Wexham Springs, D. K., pp.176-85 (1968).

(17) ARILGUIE, G.; GRANDET, J.; DUVAL, R.: "Etude du contact zinc-pâte de ciment Portland". VII Congr. Intern. Química del Cemento. Vol. III pp. VII-22-27 París (1980).

(18) ARLIQUIE, A.; GRANDET, J.: "Formation of Aureola de Transition between portland cement paste and zinc". Proc. RILEM colloq. Liasions pâtes de Ciment Materiaux Associes, Toulousse, pp. A-33/A-38 (1982).

(19) BENTUR, A.; DIAMOND, S.; MINDERS, S.: "Craking process in steel fiber reinforced cement paste". Cem. Concr. Res. Vol. 15 (2), pp. $331-342$ (1985).

(20) AL KHALAF, M. N.; PAGE, C. L.: "Steel/motar interfaces; Microestructural features and mode of failure". Cem. Conc. Res. Vol. 9, pp. 197-208 (1979).

(21) PAGE, C. L.; AL KHALF, M. N.; RITCHIE, A. G. B.: "Steel/mortar interfaces: Mechanical characteristics and electrocapillarity". Cem. Conr. Res. Vol 8(4), pp. 481-490 (1978).

(22) STRUCKE, M. S. and MAJUNDAR, A. J.: "Microestructure of glass fibre-reinforced cement composities". Journal of Material Science, 11, pp. 1.019-1.030 (1976).

(23) COHEN E. B.; DIAMOND, S.: "Fibre Reinforced Cement and Concrete". Proc RILEM Symp. The Construction Press, pp. 315 (1975).

(24) BENTUR, A. Comunicación Privada.

(25) AMAT, L.; BLANCO, M. T.; PALOMO A.; PUERTAS, F.: "Comportamiento de fibras acrílicas como refuerzo en pasta de cemento". X inter. American Conf. on Materials Technology. San Antonio. Texas (USA), (1989).

(26) PUERTAS, F.; BLANCO, M. T.; PALOMO, A.: "Microscopic analysis on the behavior of acrilic fibers inmersed in media simulating the aqueous phase of concrete arid embebbed in cement paste". 12th ICMA conference. USA (1990).

\section{publicación del ICCET/CSIC}

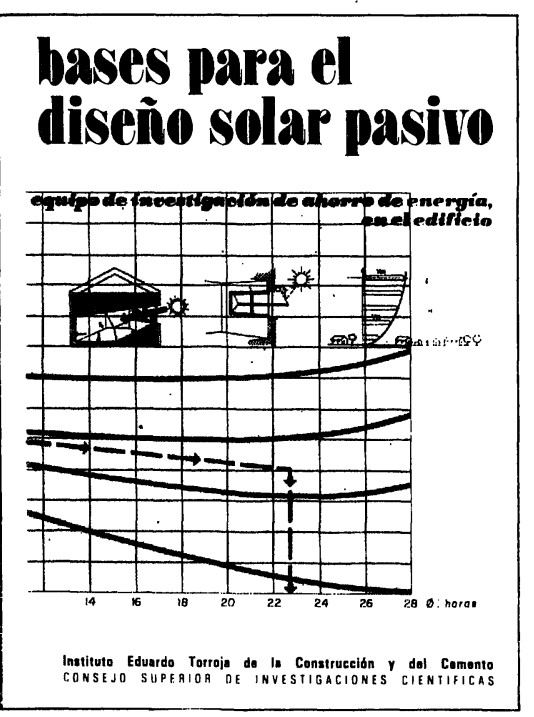

106
Equipo de Ahorro de Energía en el edificio

Dirección y coordinación: Arturo García Arroyo

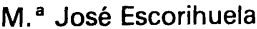
José Luis Esteban José Miguel Frutos Manuel Olaya Bernardo Torroja
Las dificultades de suministro y el alto coste de los productos energéticos convencionales han despertado la atención de los usuarios, técnicos e industriales de la edificación hacia los procedimientos y sistemas en que se basa el aprovechamiento de otras fuentes alternativas de energia, principalmente la solar. Esto ha generado un rápido desarrollo industrial $y$ comercial que, en opinión de los autores de este libro, arrast un mimético tecnologismo respecto de los sistemas convencionales que violenta las peculiaridades de la energia solar (baja densidad y variabilidad en el tiempol, y una escasa selectividad en la aplicación de los sistemas y procedimientos pasivos dando origen a un ecumenismo arquitectónico solar, al margen de las condiciones climáticas y funcionales especificas de cada caso y lugar.

En este libro, utilizando criterios y metodologia pedagógicos, se dan los fundamentos e instrumentos teórico-prácticos necesarios para el planteamiento de todo proyecto arquitectónico solar pasivo, de acuerdo con los principios éticos y económicos de conservación y ahorro de energía. Es decir: respeto de los presupuestos bioclimáticos, búsqueda de la máxima captación y acumulación de la radiación solar, y esmero en el aislamiento térmico de los cerramientos.

Un volumen encuadernado en cartulina ibiza plastificada, a cinco colores, de $16 \times 23 \mathrm{~cm}$, compuesto de 216 páginas, 217 figuras, 87 gráficos, 19 tablas y 10 cuadros. 